\title{
2019 Award for Impact on the Teaching and Learning of Mathematics
}

M. VAli Siadat of Richard J. Daley College, one of the City Colleges of Chicago, has been named the recipient of the 2019 AMS Award for Impact on the Teaching and Learning of Mathematics.

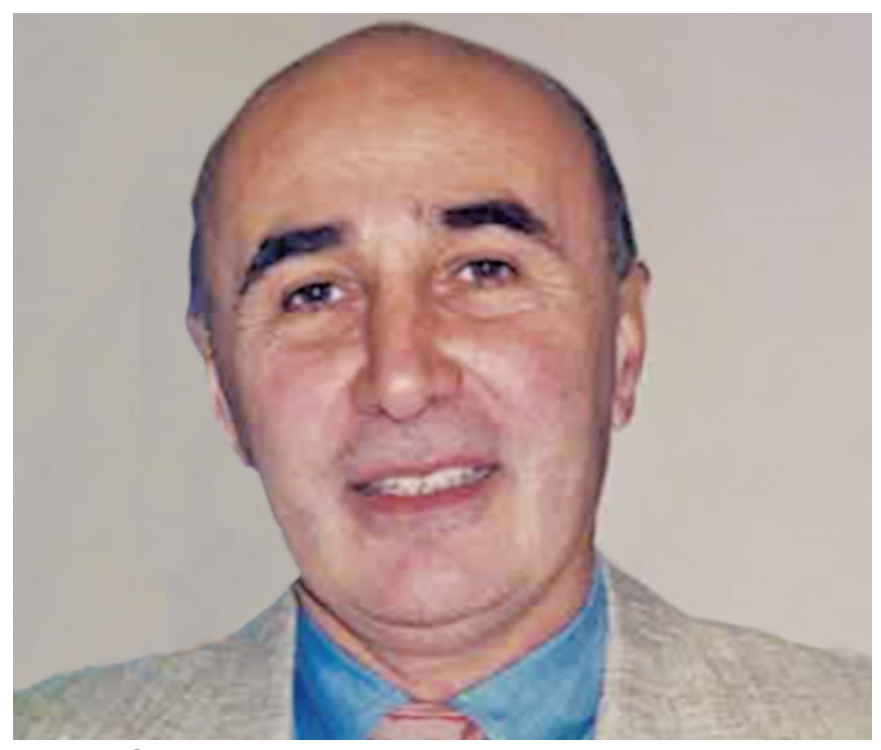

M. Vali Siadat

\section{Citation}

Dr. M. Vali Siadat is a Distinguished Professor of Mathematics at Daley College, one of the City Colleges of Chicago. An accomplished mathematician with two doctoral degrees, Dr. Siadat's life and work reflect a passionate dedication to student achievement in mathematics, focusing on the critical period between late high school and early college. Dr. Siadat led the Project Access/Chicago Prep program, an integral part of a NASA national mathematics project targeting promising low-income and minority students. Apart from directing the local program and teaching and

For permission to reprint this article, please contact: reprint - permission@ams.org.

DOI: https://dx.doi.org/10.1090/noti 1866 mentoring 80-100 middle and high school students every summer from 1996 to 2004, he developed the curriculum related to mathematical logic and computer science for the national program. Dr. Siadat is perhaps best known for his Keystone Project, developed in close partnership with his two-time dissertation advisor, Professor Sagher, in which he worked on improving freshman and sophomore performance through frequent student assessment and feedback, adjusting teaching practices, and building study skills to achieve mastery of the topics. This research showed that the proper use of mathematics can actually improve one's working memory toward enhancing fluid intelligence.

Built on his belief that mathematics can be a keystone to student learning, the Keystone program for teaching mathematics has helped students at different college levels. For example, in a multiyear study involving hundreds of community college students, the method led to an increase in student success in Elements of Algebra to 59\%, as compared to $18 \%$ in the control group. Interestingly, without teaching any reading, it also led to a 12.3 percentile-point increase in reading comprehension scores of students, which could be attributed to their improved concentration skills. The control group showed no increase in the reading scores. The cumulative data also confirmed that the retention rate for the project classes was $74 \%$ versus $67 \%$ in traditional classes.

Dr. Siadat has made significant contributions toward improving mathematics education at the precollege and two-year college levels through regional and national projects, research, and presentations. His influence is not just limited to the students at his own institution, as is evident from the many honors he has received from various regional and national organizations, including the Carnegie Foundation for the Advancement of Teaching and 
Council for Advancement and Support of Education, the Illinois Council of Teachers of Mathematics, the National Council of Instructional Administrators, the University of Illinois at Chicago, the Illinois Community College Board, the National Institute for Staff and Organizational Development, Northeastern Illinois University, and the Mathematical Association of America. Dr. Siadat's work is a gift both to his many generations of students and to mathematics education.

For his many sustainable and replicable contributions to mathematics and mathematics education at both the precollege and college levels, the AMS Committee on Education is delighted to award Dr. M. Vali Siadat the AMS Award for Impact on the Teaching and Learning of Mathematics.

\section{Biographical Note}

M. Vali Siadat earned his BSEE from the University of California, Berkeley, and, later on, an MSEE from San Jose State University, while working as a professional engineer in the Silicon Valley in California. Throughout his academic and professional work, however, mathematics remained the subject of his utmost passion. With the desire to get rigorous training in mathematics and inspired by teaching in this subject, he pursued his intensive graduate studies in mathematics, resulting in his being awarded an MS in applied mathematics, a PhD in pure mathematics (harmonic analysis), and a DA (Doctor of Arts) degree in mathematics, majoring in mathematics education with a minor in applied statistics, from the University of Illinois at Chicago (UIC). He earned his doctoral degrees under the supervision of his two-time dissertation advisor and mentor, Professor Yoram Sagher.

Dr. Siadat has previously taught at several institutions of higher learning, including California State University at Dominguez Hills, the University of Southern California, Chicago State University, Loyola University Chicago, and the City Colleges of Chicago, where he is currently distinguished professor of mathematics at its Richard J. Daley campus. He was the Director/Co-Principal Investigator of a grant of over three quarters of a million dollars from NASA to conduct the Project Access/Chicago PREP program. He was also the Director/Co-Principal Investigator of a grant of nearly US $\$ 100,000$ from Gabriella and Paul Rosenbaum Foundation intended to expand the Keystone Project. Dr. Siadat has extensive publications in mathematics and mathematics education journals and has had numerous presentations at local, statewide, and national mathematics meetings.

Dr. Siadat won the Distinguished Professor Award of Richard J. Daley College in 1999-2000. He won the 1999 Exemplary Initiatives in the Classroom Award from the National Council of Instructional Administrators, the 2001 Award for Excellence in Teaching from the Illinois Council of Teachers of Mathematics, and the 2001 Excellence in
Learning-Centered Instruction Award from the Illinois Community College Board. He received the MAA Illinois Section's Outstanding Teaching Award in 2002 and the Carnegie Foundation for the Advancement of Teaching and Council for Advancement and Support of Education Illinois Professor of the Year Award in 2005, followed by the 2009 NISOD Excellence Award from the University of Texas at Austin. He was also awarded the 2009 Mathematical Association of America's Deborah and Franklin Tepper Haimo Award for distinguished teaching of mathematics.

\section{Response}

I am deeply honored to have received this prestigious award. Let me first highly commend the American Mathematical Society for creating this award in recognition of the importance of the mathematics education of the young minds attending colleges and universities in the United States. This is another testimonial that AMS not only promotes pure mathematics research and scholarship but also supports and promotes the efforts to upgrade the mathematics education of our precollege and college students. Let me also thank the AMS Committee on Education and the Awards Committee for bestowing upon me this great honor. I am immensely grateful.

\section{About the Award}

The Award for Impact on the Teaching and Learning of Mathematics was established by the AMS Committee on Education (COE) in 2013. The US $\$ 1,000$ award is given annually to a mathematician (or group of mathematicians) who has made significant contributions of lasting value to mathematics education. Priorities of the award include recognition of (a) accomplished mathematicians who have worked directly with precollege teachers to enhance teachers' impact on mathematics achievement for all students, or (b) sustainable and replicable contributions by mathematicians to improve the mathematics education of students in the first two years of college. The endowment fund that supports the award was established in 2012 by a contribution from Kenneth I. and Mary Lou Gross in honor of their daughters Laura and Karen. The award is presented by the AMS COE acting on the recommendation of a selection subcommittee. For the 2019 award, the members of the subcommittee were:

- Douglas Ensley

- Manmohan Kaur (chair)

- Jon Wilkening

A list of previous recipients of the Impact Award may be found on the AMS website at: www.ams.org /profession/prizes-awards/ams-awards/impact.

\section{Credits}

Photo of M. Vali Siadat is by Neil Stern. 